УдК 342.5

\author{
H. B. Miшuна
}

\title{
АКТУАЛЬНІ ПРОБЛЕМИ ВИКЛАДАННЯ МУНІЦИПАЛЬНОГО ПРАВА УКРАЇНИ
}

Демократичні перетворення в Україні все частіше привертають увагу до необхідності інтенсифікації муніципальної реформи. Нові ініціативи Президента та Уряду України в цій сфері, децентралізаційні прагнення зумовлюють підвишення інтересу студентів - майбутніх юристів до такої навчальної дисшипліни, як «Муніципальне право України».

Уже протягом більше ніж десятиріччя «Муніципальне право України» посідає важливе місце серед інших дисциплін, викладання яких забезпечується кафедрою конституційного права Національного університету «Одеська юридична академія». Наразі воно виклајається тільки на 4 курсі судово-адміністративного факультету. За навчальним планом на «Муніципальне право України» відводиться 90 годин, у т. ч. 32 години лекцій і 30 годин практичних (семінарських) занять. Можливість перегляду ціннісно-цільових основ викладання цієї навчальної дисципліни та приведення іiі робочої програми у відповідність із найсучаснішими викликами побудови демократичного суспільства зумовлюють актуа.льність статті.

Питання, пов'язані з концептуальними підходами до викладання муніципального права України, аналізували такі відомі фахівці в цій сфері, як М.О. Баймуратов, Ю.Ю. Бальцій, О.В. Батанов, А.Р. Крусян, П.М. Любченко, М.П. Орзіх, Б.А. Пережняк, О.Ф. Фрицький та інші. Більшість із них $є$ авторами i/або співавторами підручників із навчальної дисципліни «Мунішипальне право України».

Метою статті $€$ аналіз актуальних проблем, пов'язаних із викладанням навчальної дисципліни «Муніципальне право України», та виявлення можливих шляхів їхнього вирішення.

Свобода викладання в Україні передбачає, у тому числі, можливість викладачів на власний розсуд і виходячи зі свого досвіду викладання розробляти структуру навчальних планів, навчальної пітератури. Характеризуючи свободу викладання з позиції науки конституційного права і стосовно конституційно-правових навчальних дисциплін, С.А. Авак'ян відмітив, шо 
вона «полягає в можливості викладача викладати свій предмет, науково-гуманітарні й науково-природні істини у власному розумінні та власній інтерпретаціі. Але за будь-якого, а тим бі.льше за найширшого сприйняття категорії «свобода викладання» неодмнно виникають питання, б.лизькі до обмежень свободи виклајання: обсяг навчальної дисципліни, чи є у викладача право в межах загального обсягу курсу й матеріалу захоплюватись якимись його частинами i, відповідно, розповідати про це більше, скорочуючи інші частини курсу, навчального матеріалу. Не варто мати ілюзій і уявляти свободу викладання як абсолютну категорію. Свобода викладання в іiі конституційно-правовому контексті пов'язана 3 науковою та викладацькою етикою, 3 діловою і професійною об’єктивністю. Але важливо також, шоб ші фактори не перетворились у тяжкі кайдани для цієї конституційної свободи» [1].

Отже, під час викладання навчальної дисципліни «Муніципальне право України» автори навчальних програм виходять із низки пріоритетів у відповідній сфері.

Так, пріоритетом може бути орієнтація на типовий зміст навчальної літератури 3 дисципліни «Муніципальне право України», шоб у викладачів не виникало склајнощів із пошуком необхідних матеріалів під час розроблення лекцій і планів семінарських занять, а у студентів - під час підготовки. Наразі існує проблема з підручниками, які забезпечували б цю навчальну дисципліну. По-перше, їх не дуже багато, по-друге, чинне законодавство змінюеться швидше, ніж ці підруцники оновлюються. А отже, багато викладачів орієнтуються на зміст підручників лише при викладанні поодиноких теоретичних тем, включаючи до навчальної програми здебільшого такі теми, які вимагають переважно знайомства з чинним законодавством.

Відповідно, пріоритетом Јля авторів навчальних програм може бути максимально детальне ознайомлення студентів з особливостями законодавства про місцеве самоврядування в Україні.

Але варто відмітити, шо дисшипліна «Муніципальне право України», як правило, викладається студентам старших курсів. У зв'язку з цим для них навряд чи буде утрудненим знайомство з поточним законодавством у разі виникнення такої необхідності після завершення навчання, на практичній роботі. 3 поглялу наявних у них знань включення до навчального плану дисципліни «Муніципальне право України» переважно теоретичних конструкцій (теорій, гіпотез, концепцій) надасть можливість на прикладі такого різновиду публічної влаЈи, як муніципальна влада, повторити важливі теоретичні питання, розглянуті шодо іншого різновиду публліної влади державної влади - у курсі «Конституційне право України».

Змінити характер викладання матеріалу, збільшивши теоретичну частину курсу, важливо ще й тому, що, як влучно зазначив Н.Л. Пєшин, «ми бачимо перетворення відносин (муніципальних відносин - $/ 1$. М.) із локальних на загальні, універсальні, іхній вихід за межі територіі, обмеженої рівнем місцевого самовряЈування» [2]. 
Із цієї позиції доцільною буде зміна назви навчальної дисципліни із «Муніципальне право України» на «Муніципальне право». Адже поглиблення теоретичних знань студентів у цій сфері неодмінно викликає необхідність ілюстрування відповідних теорій, концепцій, гіпотез не тільки українським, а й зарубіжним досвідом. А напрями вирішення нагальних проблем на місцевому рівні наразі вимагають знайомства не тільки з досвідом зарубіжних країн, а й із міжнародними муніципальними стандартами.

Варто зазначити, що це потребує такого підходу до семінарів, який передбачав би не тільки опанування студентами теоретичного матеріалу, а й виконання завдань, пов'язаних із вирішенням питань проблемного характеру. Це сприятиме підвищенню прикладного значення знань, отриманих на семінарських зайняттях.

Ще одним пріоритетом може бути врахування регіональних особливостей місцевого самоврядування. Відповідно до Закону «Про місцеве самоврядування в Україні» від 21 травня 1995 р., статути територіальних громад приймаються з урахуванням історичних, національно-культурних, соціально-економічних та інших особливостей здійснення місцевого самоврядування, зокрема для м. Одеси це право порто-франко. Це також сприятиме підвишенню прикладного значення знань, отриманих на семінарських зайняттях.

Нарешті, пріоритетом має стати $і$ європейський пілхід до місцевого самоврядування. Більша частина європейських стандартів та актів рекомендаційного характеру стосовно муніципального права мають дещо інший зміст, ніж українські нормативно-правові акти в цій сфері.

Традиційно в Україні муніципальне право розглядається як інститут конституційного права, відповідно, предмет його правового регулювання не може виходити за межі предмета правового регулювання конституційного права. Предметом конституційного права зазвичай уважаються суспільні відносини, шо визначають основи правового становиша особистості й основи функціонування органів публічної влади. Відповідно, локальність значної кількості мунішипально-правових відносин (зазначені више процеси ї універсалізації стосуються не всіх відносин, пов'язаних із місцевим самоврядуванням) надає можливість визначити предметом правового регулювання муніципального права суспільні відносини, що визначають основи правового становища особистості й основи функціонування органів публічної влади в адміністративно-територіальних одиницях. Розгляд більшості підручників і навчальних програм із муніципального права України привертає увагу до того, шо іхні автори концентруються на «насиченні» курсу «Мунішипальне право України» інформацією про суспільні відносини, які визначають основи функціонування органів пуб́лічної влади в адміністративно-територіальних одиницях. Відповідно, суспільним відносинам, які регламентують основи правового становища особистості на місцевому рівні, увага майже не приділяється.

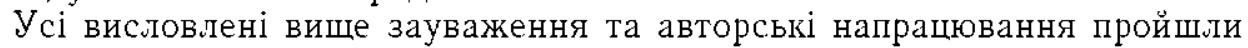
практичну апробацію під час викладання курсу «Порівняльне муніципаль- 
не право» англійською мовою (завдяки ініціативі президента Національного університету «Одеська юридична академія» С.В. Ківалова, студенти мають можливість вивчати низку дисциплін англійською мовою) [3].

Навчальна програма курсу «Порівняльне мунішипальне право» розрахована на 10 годин лекшій і 10 годин семінарських занять; за підсумками опанування матеріалу студенти складають залік.

Лекційна програма курсу охоплює 5 тем. Перша тема присвячена порівняльному підходові до муніципального права й містить необхідну теоретичну і практичну інформацію дляя більш глибокого розуміння матеріалу курсу й ефективнішого виконання творчих завдань під час підготовки до семінарських занять. У ній розглядаються питання особливостей порівняльних досліджень у муніципальному праві, зв'язок між правовими родинами та муніципальними системами, основні теорії шодо місцевого самоврядування (у т. ч. про природу й функції місцевого самоврядування). Лекцію завершує аналіз такого цікавого з погляду його змісту акта рекомендаційного характеру, як Європейська міська хартія (1992 р.).

Семінар за матеріалами цієї лекції передбачає розгляд теоретичних питань, включених до неї, а також творче письмове завдання. Творче письмове завдання пов'язано з необхідністю ознайомлення з метою, філософією та структурою Європейської міської хартії та письмового огляду одного 3 іï підрозділів. Студенти обирають один із підрозділів Розділу 4 (4.1-4.13), стисло викладають його зміст і актуальність на сучасному етапі мунішипальної реформи в Україні. Це $\epsilon$ їхньою першою спробою використання порівняльного методу для вирішення муніципально-правових проблем.

Друга лекція присвячена історії місцевого самоврядування в Україні (з поглибленням аналізом організації місцевого самоврядування протягом періодів Київської Русі, Великого князівства Литовського, Запорозької Січі, а також перебування України у складі СРСР). Після огляду історичного коріння місцевого самоврядування аналізується зміст Конституції України в частині Розділів I і XI, Закону «Про місцеве самоврядування в Україні», а також відповідних рішень Конститушійного Суду України.

Семінар на матеріалах другої лекції передбачає розгляд студентами відповідного теоретичного матеріалу, а також письмову творчу роботу щодо аналізу переглянутої Європейської хартії про участь молоді в суспі.льному житті на місцевому й регіональному рівнях (2003 р.). У письмовій роботі студенти обов'язково мають використати метод моделювання та прогнозування, запропонувавши можливі зміни в їхному політичному й суспільному житті в разі імплементашії всіх положень Хартії в Україні.

Третя лекшія передбачає аналіз найважливішого світового стандарту місцевого самоврядування - Всесвітньої декларації місцевого самоврядування 1985 р., а також напрямів діяльності ООН, що мають вплив на місцеве самоврядування. Знайомство з Програмою $\mathrm{OOH}$ щодо населених пунктів ООН-Хабітат супроводжується розглядом не тільки відповідних проектів для сусідських співтовариств, а й розглядом аналогічних інститутів в Україні - органів самоорганізації населення. 
Семінар на матеріалах третьої лекції передбачає підготовку студентами відповідного теоретичного матеріалу, а також підготовку до більш ефективного сприйняття наступної лекції. Письмова творча робота, яку студенти виконують, пов'язана з аналізом тих сучасних проб.лем місцевого самоврядування в Україні, які можливо вирішити в разі повної імплементації положень Європейської хартії місцевого самоврядування 1985 p.

Четверта лекція також присвячена стандартам у сфері місцевого самоврядування, але регіональним стандартам - європейським. Ця лекція передбачає розгляд діяльності Ради Європи та їі органів (у т. ч. Конгресу місцевих і регіональних рад), спрямованої на сприяння локальної демократії у відповідних державах. Аналізуються два європейських муніципальних стандарти - Європейська хартія місцевого самоврядування 1985 р. і Європейська конвенція про участь іноземців у суспільному житті на місцевому рівні 1992 р. На прикладі Європейської хартії місцевого самоврядування розглядаються проблеми імплементації основних принципів європейського муніципалізму в Україні (цей акт ратифіковано Законом України від 15 липня 1997 р.). На прикладі Європейської конвенції про участь іноземців у суспільному житті на місцевому рівні розгляјаються можливі трудноші в ратифікації окремих положень європейських муніципальних стандартів (ця Конвенція поки що не ратифікована Україною).

Семінар на матеріалах четвертої лекції передбачає опанування теоретичних питань за темою лекції, а також традиційну письмову творчу роботу. Цього разу увага студентів зосереджується на перспективах імплементації в Україні Європейської конвенції про участь іноземців у суспільному житті на місцевому рівні 1992 р. Вони мають визначити ті норми національного законодавства, які наразі суперечать нормам Конвенції та, відповідно, у разі її ратифікації потребуватимуть змін.

Остання лекція присвячена розгляду зарубіжного досвіду місцевого самоврядування. Лекцію починає теоретичне питання, вирішення якого $є$ різним, залежно від держави, - питання про можливість полілу муніципальної влади на три гілки, за аналогією з поділом іншого різновиду публічної влади державної влади - на законодавчу, виконавчу й судову гілки. Після цього послідовно аналізується місцеве самоврядування у США, Великій Британії та ФРН. Вибір саме цих держав пов'язаний із високим рівнем муніципальної культури в цих країнах, а також із наявністю в них кількох організаційноправових форм місцевого самоврядування для населених пунктів.

На матеріалах п'ятої лекції студенти виконують творче завдання - фінальне есе курсу. Вони проводять порівняльно-правовий аналіз місцевого самоврядування України та однієї із зарубіжних країн - США, Великої Британії та ФРН. Порівняння відбувається з обов'язковим висвітленням таких питань, як система місцевого самоврядування в порівнюваних державах, адміністративно-територіальний поділ, організаційні форми муніципального управління, види локальної демократії, компетенція органів муніципального управління, а також матеріальні основи їхного функціонування. За результатами перевірки есе студенти отримують залік. 
Отже, студенти протягом проходження курсу «Порівняльне муніципальне право» не перевантажені ні вивченням теоретичних концепцій, ні розглядом національного законодавства. Включення до матеріалів курсу міжнародних стандартів, а до підготовки до семінарських занять - завдань, які вимагають не тільки використання порівняльного методу, а й творчого підходу, спрощує сприйняття студентами ілюстрованого ними теоретичного матеріалу та сприяє кращому опануванню матеріалом. На практиці таке посилення приктадної складової семінарів повністю виправдовує себе.

Перспективи подальших досліджень у цьому напрямі вбачаються в необхідності розроблення аналогічного курсу, але розрахованого на більшу кількість годин. Також перспективним $є$ проведення всеукраїнської науково-практичної конференції, присвяченої актуальним проблемам викладання навчальної дисципліни «Мунішипальне право України».

\section{Лiтература}

1. Нудненко Л.А. Актуальные проблемы преподавания конституционного и муниципального права: обзор / Л.А. Нудненко / / Конституционное и муниципальное право. - 2008. - № 18.

2. Пешин Н.Л. Правовое регулированне местного самоуправления: проблемы теорин и практикн / Н.Л. Пешин [Ә.лектронный ресурс]. - Режнм доступа: http:/ / club.bibliopskov.ru/ index.php?option=com_content \&task=view \&id=222\&Itemid=93.

3. Mishyna N. Comparative Municipal Law: methodological manual / N. Mishyna ; National University "Odessa Academy of Law". - Odessa : Feniks, 2011. - 154 p.

\section{Анота ція}

Miuuжа H. B. Актуальні проблеми викладання муніципального права України. Стаття.

Стаття присвячена аналізу актуальних проблем викладання муніципального права України та пріоритетів, які можуть стояти перед авторами відповідних навчально-методичних матеріалів. Сформульовано внсновки й перспективи подальших досліджень в означеному напрямі. Їх проілюстровано навчально-методичними матеріалами до авторського спецкурсу «Порівняльне муніципальне право».

Клюtoвi слова: муніципальне право, порівняльне муніципальне право, публічна влала, місцеве самоврядування, децентралізація, муніципальна реформа.

\section{Ан но т а ци я}

Muuuн $\boldsymbol{H}$. B. Актуальные проблемы преподавания муниципального права Украины. - Статья.

Статья посвящена анализу актуальных проблем преподавания муннципального права Украины и приоритетов, которые могут стоять перед авторами соответствующих учебно-метолических материалов. Сформулированы выводы и перспективы дальнейших исследований в обозначенном направлении. Они проиллюстрированы учебно-методическими материалами авторского спецкурса «Сравнительное муниципальное право».

Kantegule canga: муниципальное право, сравнительное муниципальное право, публичная власть, местное самоуправление. децентрализация, муниципальная реформа. 


\section{S u ill m a r y}

Mishyna N. V. Contemporary problems of teaching the "Municipal Law of Ukraine" course. - Article.

This article analysis contemporary problems of the teaching the 'Municipal Law of Ukraine' course. A lot of attention is paid to the priorities that might be used by the specialists that develop this course. The author concludes with the proposals how to improve the situation and formulates the perspectives of the future researches in the field. The author illustrates the proposals using own methodological manual of the special course "Comparative Municipal Law" and experience of its delivery to students.

Key words: municipal law, comparative municipal law, public power, local government, decentralization, municipal reform. 